\title{
СТРУКТУРНО-ФУНКЦІОНАЛЬНА РЕАКЦІЯ ЛЕГЕНЕВОЇ ТКАНИНИ ТА СУДИН МАЛОГО КОЛА КРОВООБІГУ ЛАБОРАТОРНИХ ЩУРІВ НА РАННІЙ СТАДІЇ МОДЕЛЮВАННЯ ГОСТРОГО ПЕРИТОНІТУ
}

\author{
๑О. М. Ющак, М. В. Волошин, О. А. Луків, В. Д. Волошин, М. В. Ющак \\ ДВНЗ «Тернопільський державний медичний університет імени І. Я. Горбачевського МОз України»
}

РЕзюМЕ. Метою нашого дослідження було експериментальне вивчення морфофункціональних змін у легеневій тканині при розвитку гострого перитоніту.

Матеріал і методи. Використовували морфометричний (вимірювання товщини міжальвеолярних перегородок, діаметра альвеол); гістологічний (з метою вивчення структури легеневої тканини на світлооптичному рівні), статистичний методи. Експерименти виконано на 40 білих щурах-самцях, 10 тварин складали інтактну контрольну групу, 30 тваринам моделювали гострий перитоніт.

Результати. Незважаючи на істотний прогрес клінічної медицини, перитоніт і пов'язані з ним ускладнення залишаються однією з важливих проблем хірургічної практики. Поліорганна недостатність як наслідок гострого перитоніту $\epsilon$ вагомою причиною ускладнення захворювання і летальності, при цьому одним з перших органівмішеней $\epsilon$ легені. У дослідженні вже під час розвитку токсичної стадії гострого перитоніту спостерігали морфологічні ознаки реакцій кровоносних судин як у легенях, так і в бронхах на світлооптичному рівні. У просвітах бронхіол спостерігали злущені епітеліоцити. Реакцією на перебіг патологічного процесу стала активація секреторної функції келихоподібними клітинами слизової бронхів, локальне розширення альвеол, потовщення більшості альвеолярних перегородок. Характерна поява у цей час спазмованих бронхіол.

Висновки. Експериментальний гострий перитоніт у білих щурів-самців спричинив реакцію як на рівні епітелію бронхів, альвеол, так і в судинній ланці. Ендотоксикоз, спричинений гострим перитонітом, викликав розвиток дистрофічних процесів і порушення нормальних тканинно-судинних взаємовідносин. Протягом ранньої стадії гострого перитоніту перебіг компенсаторно-пристосувальних реакцій відбувався паралельно з розвитком ознак деструкції: спостерігали підвищення секреторної активності келихоподібних клітин, збільшення просвіту окремих альвеол, потовщення міжальвеолярних перегородок, набряки структурних елементів стінок судин.

КЛючовІ СлОВА: гострий перитоніт; легенева паренхіма; судини малого кола кровообігу; альвеоли; міжальвеолярні перегородки; ендотелій.

Вступ. Незважаючи на істотний прогрес клінічної медицини, перитоніт і пов'язані з ним ускладнення залишаються однією з важливих проблем хірургічної практики. Спостерігають щорічне зростання кількості хворих із занедбаними формами перитоніту серед осіб похилого віку, перебіг захворювання в цьому випадку є агресивним, рівень летальності становить від 19 до 30 \%, а на фоні поліорганної недостатності - до 80 \% [5]. Поліорганна недостатність залишається однією 3 вагомих причин ускладнення перебігу захворювання і летальності, при цьому одним з перших органів-мішеней за умов перитоніту $\epsilon$ легені 3 розвитком респіраторного дистрес-синдрому [4]. У свою чергу, особливістю процесів запалення у легеневій паренхімі $\epsilon$ дисплазія сполучної тканини, яка призводить до значних морфологічних та функціональних змін органів дихання, формування різноманітних клінічних проявів функціональної недостатності [6]. Як вказують дослідники, зміни в легеневій тканині можуть бути спричинені різними чинниками, зокрема опіковою травмою, панкреатитом, цукровим діабетом, кишковою непрохідністю, гострою стресовою реакцією $[1,8]$. Морфологічно це проявляється у зростанні проникності альвеолярної стінки, порушенні мікроциркуляторного русла, наявності склеротичних змін в паренхімі легень, змінами в структурі міжальвеолярних перетинок [1].

Розвиток гострого перитоніту має місце і у випадку ускладнення перебігу інших захворювань, зокрема гострого апендициту. Так, на сьогодні апендикулярний перитонінт займає перше місце за частотою серед перитонітів різноманітної етіології [2].

Дослідження патоморфологічної основи розвитку перитоніту дозволили встановити, що токсична і термінальна стадії цього захворювання за своїм характером є інфекційно-токсичним шоком, що супроводжується незворотними змінами у тканинному метаболізмі на фоні ускладнення мікроциркуляції і тяжкого порушення гомеостазу [9].

Характер змін гемодинаміки також $є$ однією 3 важливих клінічних характеристик перитоніту, адже ефективність кровопостачання органів за даних умов істотною мірою визначатиме характер дистрофічно-деструктивних процесів, глибину ураження тканин і масштаб розвитку поліорганної недостатності. Порушення мікроциркуляції поглиблює розвиток дитрофічних процесів у 
Огляди літератури, оригінальні дослідження, погляд на проблему

тканинах вогнища запалення, що вже на ранніх стадіях розвитку перитоніту призводить до деструкції клітинних структур. Встановлено, що деструкційні зміни слизової оболонки тонкої кишки розвиваються вже від 24 год експериментального перитоніту, при цьому спостерігали зменшення розмірів келихоподібних клітин, стоншання та руйнування слизового шару [3]. Ендотоксикоз, що розвивається за умов перитоніту, є одним з вагомих факторів ускладнення перебігу захворювання, тому ще одним важливим напрямом досліджень $є$ визначення ефективності різних підходів до системної етіотропної антибактеріальної терапії за клінічними даними [7].

Метою нашої роботи було експериментальне вивчення морфофункціональних змін у легеневій тканині за умов ранньої стадії гострого перитоніту.

Матеріал і методи. Використовували морфометричний (вимірювання товщини міжальвеолярних перегородок, діаметра альвеол); гістологічний (з метою вивчення структури легеневої тканини на світлооптичному рівні), статистичний методи.

Експерименти виконано на 40 білих щурах-самцях. 10 тварин складали інтактну контрольну групу, 30 тваринам моделювали гострий перитоніт шляхом внутрішньоочеревинного введення 10 \% калової суміші. Усі втручання та забій тварин проводили з дотриманням принципів «Європейської конвенції про захист хребетних тварин, які використовуються для експериментальних та інших наукових цілей» (Страсбург, 1985), ухвалених Першим національним конгресом з біоетики (Київ, 2001).

Одержаний в результаті експерименту цифровий матеріал був оброблений за методом Стьюдента на персональному комп'ютері за допомогою програми Excel. Достовірною вважали імовірність помилки при $\mathrm{P}<0,05$.

Вже на ранній стадії розвитку перитоніту показовим фактом $\epsilon$ виявлення транссудату не лише у черевній, але й у плевральній порожнині. Це можна розцінювати як свідчення первинності судинних змін за умов даного патологічного процесу. Під час розвитку токсичної стадії гострого перитоніту світлооптично спостерігали морфологічні ознаки реакцій кровоносних судин, як відповіді організму на порушення гемодинаміки. Слід зазначити, що зміни виникали одночасно як в бронхіальних судинах, що належать до великого кола кровообігу, так і в судинах легень (мале коло кровообігу), тобто структурна реакція судин мала неспецифічний характер. Під час токсичної стадії (в перші 6 год) гострого перитоніту органні судинні реакції проявлялися спастичним скороченням артеріол і повнокров'ям капілярів. Через 12 год, крім змін у артеріолах і капілярах, спостерігали підвищення тонусу артерій м'язового типу з паралельним ак- тивним наростанням повнокров'я як в артеріальній, так і у венозній ланках судинного русла легень.

Підвищення тонусу артеріальних судин супроводжувалося явищем складчастості (так званої «гофрованості») їх внутрішніх еластичних мембран, потовщенням м'язових оболонок з одночасним звуженням просвіту. Отримали розвиток набряки в структурних елементах стінок судин. Як наслідок, цитоплазма гладком'язових клітин виглядала просвітленою, відбувалось набухання ядер ендотелію та їх випинання у просвіт артерій.

У просвітах бронхіол спостерігали злущені епітеліоцити. Реакцією на перебіг патологічного процесу стала активація секреторної функції келихоподібними клітинами слизової бронхів, локальне розширення альвеол, потовщення більшості альвеолярних перегородок. Підвищену секреторну активність келихоподібних клітин відзначено протягом 36 год від початку експерименту. Характерна поява у цей час спазмованих бронхіол з просвітом зірчастої форми.

На початок другої доби експерименту реакція на розвиток гострого перитоніту з боку судин поглибилась, спостерігали зниження тонусу артерій м'язового типу, зменшення звивистості внутрішніх еластичних мембран, розширення просвіту цих судин. Ці зміни судин відбувались на фоні збереження артеріального і венозного повнокров'я і розкриття артеріовенозних анастомозів.

Результати морфометрії показали, що протягом перших 6 годин експериментального перитоніту мало місце реактивне збільшення просвіту

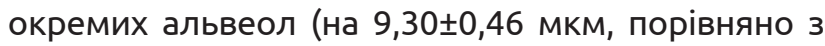
контролем) внаслідок інтенсифікації дихальної функції у відповідь на гіпоксію. Однак у подальшому морфометричні дослідження показали поступове звуження діаметрів альвеол (в середньому на $(23,7 \pm 1,83)$ мкм, порівняно з показником інтактних тварин) і бронхіального просвіту та істотне потовщення міжальвеолярних перегородок - в середньому на $(2,1 \pm 0,12)$ мкм у перші 6 год і на $(9,1 \pm$ $0,39)$ мкм - на 36 год від початку експерименту.

Висновки. 1. Модельований експериментально гострий перитоніт у білих щурів-самців спричинив реакцію як на рівні епітелію бронхів, альвеол, так і в судинній ланці. Ендотоксикоз, спричинений гострим перитонітом, викликав розвиток дистрофічних процесів і порушення нормальних тканинно-судинних взаємовідносин.

2. Протягом ранньої стадії гострого перитоніту перебіг компенсаторно-пристосувальних реакцій відбувався паралельно з розвитком ознак деструкції: спостерігали підвищення секреторної активності келихоподібних клітин, збільшення просвіту окремих альвеол, потовщення міжальвеолярних перегородок, набряки структурних елементів стінок судин. 
Огляди літератури, оригінальні дослідження, погляд на проблему

3. Перебіг ранньої стадії гострого перитоніту супроводжувався спастичними реакціями легеневих судин, підвищенням проникності стінок судин і формуванням набряків в інтерстиції та паравазальних просторах.

Перспективи подальших досліджень. Вивчення особливостей структурної реакції паренхі- ми легень та судин малого кола кровообігу на вплив експериментального гострого перитоніту $\epsilon$ частиною комплексного дослідження. Отримані дані можуть бути використані у розробці методів, спрямованих на оптимізацію лікування наслідків токсичного шоку і дистрофічно-деструктивних процесів за умов гострого перитоніту.

\section{ЛІТЕРАТУРА}

1. Банул Б. Ю. Функціональні та структурні зміни в органах дихальної системи під впливом різних чинників / Б. Ю. Банул, Б. Г. Макар // Клінічна анатомія та оперативна хірургія. - 2014. - Т. 13, № 2. - С. 94-98.

2. Білик I. І. Гострий перитоніт як ускладнення гострого апендициту [Електронний Ресурс] / І. І. Білик // Клінічна та експериментальна патологія. - 2013. - Т. 12, № 1 (43).-С. 187-189. Режимдоступудо журналу: https:// www.bsmu.edu.ua/files/KEP/\%CA\%C5P-2013-01/187. pdf - Назва з екрану. - Дата звернення: 03.05.2017.

3. Войтів Я. Ю. Профілактика та лікування кишкової недостатності при перитоніті : автореферат дис. на здобуття наукового ступеня канд. мед. наук: спец. 14.01.03 «Хірургія» / Я. Ю. Войтів // Львівський національний медичний університет ім. Данила Галицького МОЗ України. - Львів, 2010. -21 с.

4. Особливості динаміки морфофункціональних змін у коронарному руслі та судинах малого кола кровообігу при перебігу гострого розлитого перитоніту / І. Є. Герасимюк, В. О. Чепесюк, А. В. Гантімуров, Л. О. Герасимюк // Здобутки клінічної і експериментальної медицини. - 2009. - № 2. - С. 35-38.

\section{REFERENCES}

1. Banul, B.Yu., \& Makar B.H. (2014). Funktsionalni ta strukturni zminy $v$ orhanakh dykhalnoi systemy pid vplyvom riznykh chynnykiv [Functional and structural changes in the respiratory system under the influence of various factors]. Klinichna anatomiia ta operatyvna khirurhiia - Clinical Anatomy and Operative Surgery, 13, 2, 94-98 [in Ukrainian].

2. Bilyk, I.I. (2013). Hostryi perytonit yak uskladnennia hostroho apendytsytu [Acute peritonitis as a complication of acute appendicitis]. Klinichna ta eksperymentalna patolohiia - Clinical and Experimental Pathology, 12, 1 (43), 187-189. Retrieved from https://www.bsmu.edu.ua/files/ KEP/ \%CA \%C5P-2013-01/187.pdf [in Ukrainian].

3. Voitiv, Ya.Yu. (2010). Profilaktyka ta likuvannia kyshkovoi nedostatnosti pry perytoniti [Prevention and treatment of intestinal failure at peritonitis]. Extended $a b$ stract of Candidate's thesis. Lviv: Danylo Halytskyi National Medical University [in Ukrainian].

4. Herasymiuk, I.Ye., Chepesuk, V.O., Hantimurov, A.V., \& Herasymiuk, L.O. (2009). Osoblyvosti dynamiky morfofunktsionalnykh zmin u koronarnomu rusli ta sudynakh maloho kola krovoobihu pry perebihu hostroho rozlytoho perytonitu [The features of dynamics of morphological
5. Динаміка показників CD8-лімфоцитів при пролонгованому інтраабдомінальному сорбційно-трансмембранному діалізі у хворих з розповсюдженим перитонітом / С. О. Мунтян, В. П. Кришень, С. І. Баранник [та ін.] // Актуальні проблеми сучасної медицини. 2014. - Т. 14, Вип. 2 (46). - С. 83-85.

6. Пальчик С. М. Морфоклінічні та променеві аспекти діагностики бронхолегеневих захворювань та їх ускладнень в дітей з дисплазією сполучної тканини / С. М. Пальчик, І. М. Вороньжев, І. О. Крамний // Перинатология и педиатрия. - 2016. - № 2 (66). - С. 133-139.

7. Клінічне дослідження чутливості збудників гострого перитоніту до антимікробних препаратів / В. П. Польовий, Р. І. Сидорчук, А. С. Паляниця [та ін.] // Клінічна анатомія та оперативна хірургія. -2014. - Т. 13, № 3. - С. 32-34.

8. Пронина О. М. Преморбідні зміни легеневої тканини внаслідок гострої стресової реакції в експерименті / О. М. Пронина, М. М. Коптев, С. І. Данильченко, О. Ю. Половик // Вісник проблем біології і медицини. 2011. - Вип. 3, Т. 2 (88). - С.154-156.

9. Струков А. И. Острый разлитой перитонит : под ред. А. И. Струкова, В. И. Петрова, В. С. Паукова; АМН СССР. - М. : Медицина, 1987. -288 С.

changes in the coronary vessels and pulmonary circulation during the course of acute diffuse peritonitis]. Zdobutky klinichnoi i eksperymentalnoi medytsyny - Achievements of Clinical and Experimental Medicine, 2, 35-38 [in Ukrainian].

5. Muntian, S.O., Kryshen, V.P., Barannyk, S.I., Liashchenko P.V., \& Likholetov Ye.O. (2014). Dynamika pokaznykiv CD8-limfotsytiv pry prolonhovanomu intraabdominalnomu sorbtsiino-transmembrannomu dializi u khvorykh z rozpovsiudzhenym perytonitom [Dynamics of CD8-lymphocyte counts with prolonged intra-abdominal sorption-transmembrane dialysis in patients with advanced peritonitis]. Aktualni problemy suchasnoi medytsyny-Actual Problems of Modern Medicine, 14, 2 (46), 83-85 [in Ukrainian].

6. Palchyk, S.M., Voronzhev, I.O., \& Kramnyi, I.O. (2016). Morfoklinichni ta promenevi aspekty diahnostyky bronkholehenevykh zakhvoriuvan ta yikh uskladnen v ditei $z$ dysplaziieiu spoluchnoi tkanyny [Morpho-clinical and radiation aspects of diagnosis of bronchopulmonary diseases and their complications in children with connective tissue dysplasia]. Perinatologiya i pediatriya - Perinatology and Pediatrics, 2 (66), 133-139 [in Ukrainian].

7. Poliovyi, V.P., Sydorchuk, R.I., Palianytsia, A.S., Kulachek, Ya.V., Nurdipov, Kh.N., \& Hrodetskyi, V.K. (2014). 
Огляди літератури, оригінальні дослідження, погляд на проблему

Klinichne doslidzhennia chutlyvosti zbudnykiv hostroho perytonitu do antymikrobnykh preparativ [Clinical study of sensitivity of pathogens of acute peritonitis to antimicrobial drugs]. Klinichna anatomiia ta operatyvna khirurhiia - Clinical Anatomy and Operative Surgery, 13, 3, 32-34 [in Ukrainian].

8. Pronyna, O.M., Koptev, M.M., Danylchenko, S.I., \& Polovyk, O.Yu. (2011). Premorbidni zminy lehenevoi tkany-

ny vnaslidok hostroi stresovoi reaktsii v eksperymenti [Premorbid changes in pulmonary tissue due to acute stress reaction in the experiment]. Visnyk problem biolohii $i$ medytsyny - Journal of the Problems of Biology and Medicine, 3, 2 (88), 154-156 [in Ukrainian].

9. Strukov A.I., Petrova V.I., \& Paukova V.S. (Eds.). (1987). Ostryy razlitoy peritonit [Acute diffuse peritonitis]. Moscow: Medicine [in Russian].

\title{
СТРУКТУРНО-ФУНКЦИОНАЛЬНАЯ РЕАКЦИЯ ЛЕГОЧНОЙ ТКАНИ И СОСУДОВ МАЛОГО КРУГА КРОВООБРАЩЕНИЯ ЛАБРАТОРНЫХ КРЫС НА РАННИХ СТАДИЯХ МОДЕЛИРОВАНИЯ ОСТРОГО ПЕРИТОНИТА
}

\author{
๑О. М. Ющак, М. В. Волошин, О. А. Лукив, В. Д. Волошин, М. В. Ющак
}

ГВУз «Тернопольский государственный медицинский университет имени И. Я. Горбачевского»

РЕЗЮМЕ. Целью нашего исследования было экспериментальное изучение морфофункциональных изменений в легочной ткани при развитии острого перитонита.

Материал и методы. Использовали морфометрические (измерение толщины межальвеолярных перегородок, диаметра альвеол), гистологический (с целью изучения структуры легочной ткани на светооптическом уровне), статистический методы. Эксперименты выполнены на 40 белых крысах-самцах, 10 животных составляли интактную контрольную группу, 30 животным моделировали острый перитонит.

Результаты. Несмотря на существенный прогресс клинической медицины, перитонит и связанные с ним осложнения остаются одной из важных проблем хирургической практики. Полиорганная недостаточность как следствие острого перитонита является весомой причиной осложнения заболевания и летальности, при этом одним из первых органов-мишеней являются легкие. В исследовании уже во время развития токсической стадии острого перитонита наблюдали морфологические признаки реакций кровеносных сосудов как в легких, так и в бронхах, на светооптическом уровне. В просветах бронхиол наблюдали слущенные эпителиоциты. Реакцией на течение патологического процесса стала активация секреторной функции бокаловидных клеток слизистой бронхов, локальное расширение альвеол, утолщение большинства альвеолярных перегородок. Характерно появление в это время спазмированных бронхиол.

Выводы. Экспериментальный острый перитонит у белых крыс-самцов вызвал реакцию как на уровне эпителия бронхов, альвеол, так и в сосудистом звене. Эндотоксикоз, вызванный острым перитонитом, инициировал развитие дистрофических процессов и нарушение нормальных тканево-сосудистых взаимоотношений. В ранней стадии острого перитонита течение компенсаторно-приспособительных реакций происходило параллельно с развитием признаков деструкции: наблюдали повышение секреторной активности бокаловидных клеток, увеличение просвета отдельных альвеол, утолщение межальвеолярных перегородок, отеки структурных элементов стенок сосудов.

КЛЮЧЕВЫЕ СЛОВА: острый перитонит; легочная паренхима; сосуды малого круга кровообращения; альвеолы; межальвеолярные перегородки; эндотелий.

\section{STRUCTURAL AND FUNCTIONAL REACTION OF PULMONARY TISSUE AND BLOOD VESSELS OF PULMONARY CIRCULATION OF LABORATORY RATS AT THE EARLY STAGES OF MODELING OF ACUTE PERITONITIS}

\author{
๑O. M. Yushchak, M. V. Voloshyn, O. A. Lukiv, V. D. Voloshyn, M. V. Yushchak \\ I. Horbachevsky Ternopil State Medical University
}

SUMMARY. The aim of our research was the experimental study of morphological and functional changes in lung tissue in the development of acute peritonitis.

Materials and Methods. Morphometric (measurement of interalveolar septa thickness, diameter of alveoli), histological for studying of lung tissue structure on the light-optical level, statistical. The experiment was performed on 40 white male rats: 10 animals were as an intact control group, 30 animals were modeled with acute peritonitis. 
Огляди літератури, оригінальні дослідження, погляд на проблему

Research Results. Despite the significant progress of clinical medicine, peritonitis and its associated complications are the one of the important problems of surgical practice. Polyorgan failure (as a consequence of acute peritonitis) is an important cause of complication of the disease and lethality. And the lungs are the one of the first target of this disease. In the study, already during the development of the toxic stage of acute peritonitis, the morphological signs of the reactions of blood vessels in both the lungs and bronchial were observed light-optically. The desquamated epithelial cells were observed in the lumens of bronchioles. Activation of the secretory function of goblet cells of bronchial mucosa, local expansion of alveoli, thickening of most alveolar septa became a reaction to the course of the pathological process. The appearance of spasmodic bronchioles was characteristic at this time.

Conclusions. Experimental acute peritonitis in white male rats caused a reaction in the bronchi epithelium, in alveoli and in the vascular system of lung. The acute peritonitis initiates endotoxicosis and development of dystrophic processes and disruption of normal tissue-vascular interactions. In the early stage of acute peritonitis, the course of compensatoryadaptive reactions occurred in parallel with the development of signs of destruction: an increase in the secretory activity of goblet cells, increasing clearance of some alveoli, thickening of interalveolar septa, edema of structural elements of the walls of the blood vessels.

KEY WORDS: acute peritonitis; pulmonary parenchyma; vessels of pulmonary circulation; alveoli; interalveolar septa; endothelium.

Отримано 10.05.2017. 